\title{
Salvinia natans in medieval wetland deposits in Gdańsk, northern Poland: evidence for the early medieval climate warming
}

\author{
Joanna Święta-Musznicka • Małgorzata Latałowa • \\ Józef Szmeja $\cdot$ Monika Badura
}

Received: 21 December 2009/ Accepted: 28 January 2011/Published online: 15 February 2011

(C) The Author(s) 2011. This article is published with open access at Springerlink.com

\begin{abstract}
Large numbers of sub-fossil remains of the aquatic fern Salvinia natans (L.) All. have been found in several early medieval sites in Gdańsk, N. Poland. This record indicates a population expansion of this species around 7th-8th century A.D., similar to the recently observed rapid spread and high population dynamics of $S$. natans in northern Poland, which recent studies have attributed to climate warming. Our results suggest that in the Vistula deltaic area the $S$. natans expansion in the Early Middle Ages (7th-8th century A.D.) was similarly stimulated by climate warming, while its subsequent decline was mainly due to climate cooling, especially during the Little Ice Age. Warmer winters and springs and a longer growing season seem to be the most important factors forcing the expansion of $S$. natans in medieval times. According to our data, the co-occurrence of $S$. natans with other aquatic plant species was similar in both the medieval and presentday vegetation. Also, the high density of $S$. natans in the medieval population caused impoverishment of the local ecosystems in a way that has been observed in recent water bodies affected by invasive pleustophytes (free-floating plants).
\end{abstract}

J. Święta-Musznicka · M. Latałowa ( $₫)$.

J. Szmeja · M. Badura

Department of Plant Ecology, University of Gdańsk,

Al. Legionów 9, 80-441 Gdańsk, Poland

e-mail: bioml@univ.gda.pl
Keywords Early medieval climate warming · Palaeolimnology · Palaeoecology · Invasive plants · Aquatic ecosystems - Salvinia natans .

Vistula deltaic area

\section{Introduction}

Palaeoecological data from both natural and anthropogenic deposits are the main source of information about both the past distribution of various species and the formation and dynamics of plant communities. Data about species that have recently become rare or those with very specific ecological requirements are of special value, giving clues regarding different aspects of environmental change (Leroy 1992; Wolters et al. 2005; Brinkkemper et al. 2008).

Archaeological sites provide important botanical material comprising not only the remains of useful plants but also representatives of the vegetation that developed both on the site and in its surroundings (Latałowa et al. 2003; Pokorný et al. 2006). By compiling the data from consecutive periods, it is possible to reconstruct changes in plant communities under specific forms and at different scales of human interference (Behre and Jacomet 1991; Kozáková et al. 2009). Through the use of the bio-indicator characters of the species identified in the fossil material, changes in other environmental factors, primarily climate and hydrology, can be described.

Large-scale archaeobotanical research in historical Gdańsk, N. Poland, involving both on-site pollen and 
macrofossil studies, has been used to reconstruct environmental changes of the area through time (Latałowa et al. 2009). Samples for plant macroremains and pollen analyses were taken from culture layers of different origin, including moats, ditches and other water-bodies, and from the layers situated beneath archaeological features. Thus, the results document vegetation and ecological conditions in a period immediately preceding occupation of particular sites and in the subsequent centuries. Among the numerous plant species identified in the fossil material, the exceptionally large numbers of mega- and microspores, and fragments of sporocarps of Salvinia natans (L.) All. make this species of special interest.

In the European Pollen Database (http://www. europeanpollendatabase.net), out of a total of more than one thousand pollen sequences, only a few Holocene sites with $S$. natans pollen are indicated, none of them in Central Europe. This means that even though these data do not give complete geographical coverage (Zandstra 1966; Latałowa and Święta 2003; Out 2008), this species is relatively rare in palaeoecological sites, which makes the record from Gdańsk even more interesting.

The causes and mechanisms of biological invasions and their environmental effects are among the most thoroughly disputed topics in present-day ecology (Dukes and Mooney 1999; Walther et al. 2002; MacDougall and Turkington 2005). Human activities and climate change are among important factors affecting species expansion and population dynamics (Rejmánek 1995; Walther et al. 2002).

The aim of the present paper is to examine arguments for our hypothesis that the large numbers of fossil remains of $S$. natans in early medieval deposits in Gdańsk might reflect a population expansion of this species similar to that recently observed in the Gdańsk region (Markowski et al. 2004). We will also discuss the possible factors responsible for this phenomenon in medieval Gdańsk.

Salvinia natans: present-day geographical

distribution, ecological requirements, and population dynamics in the Vistula deltaic area

Salvinia natans (L.) All. is a small aquatic fern, typically growing in a sub-tropical and warm sub-oceanic temperate climate, with a large, natural distribution range extending from northern China to India and then to southern and central Europe and northern Africa (Herzog 1938). In recent times, it continues to be spread by humans to other regions of the world (Holm et al. 1979). In Europe, it occurs mainly in the drainage basins of large rivers (Casper and Krausch 1980), in oxbowlakes, ditches and channels, and in shallow, slowly flowing rivers. This species tolerates a wide range of habitat conditions, however, it prefers calm, shallow, eutrophic waters and a thick layer of organic substrate in the bottom sediments. Its abundant occurrence changes environmental conditions in the whole ecosystem and thus controls the development of other aquatics (Zutschi and Vass 1971). In Europe it forms an association described as Lemno minoris-Salvinietum natantis (Slavnič 1956) Korneck 1959 together with Spirodela polyrhiza (L.) Schleid., Lemna minor L., L. trisulca L., Hydrocharis morsus-ranae L., Nuphar lutea (L.) Sibth. \& Sm., Ceratophyllum demersum L. s. s. and others (Michalska-Hejduk and Kopeć 2002).

S. natans is an annual free-floating and clonal plant (Zutschi and Vass 1971) producing sporocarps in the late summer (August-September). At the end of the growing season these become detached and are left freely floating as they do not sink to the bottom sediments. Above zero winter temperatures are crucial for the survival of its micro- and megaspores, which are killed when frozen. Germination of spores starts effectively in temperatures above $12.4 \pm 0.2^{\circ} \mathrm{C}$ and the young sporophyte developing at the water surface does not survive if frozen (Gałka 2011). The sporophyte is delicate and breaks easily, but the ramets develop into new plants that might be transported along water currents or with floods. The high ability to propagate vegetatively is one of the most important features of $S$. natans's expansion success.

In Poland, about $75 \%$ of $S$. natans localities occur in the southern part of the country, $10 \%$ in the central part and about $15 \%$ in the north. Gdańsk (the Vistula deltaic area) lies at the northern limit of the European distribution range of this species. The first written information on the occurrence of $S$. natans in this region, in $\mathrm{AD} 1873$, was given by Abromeit et al. (1940). Until 1999, i.e. for 126 years following 1873, small populations of this species were recorded in 17 localities. A rapid change took place between 2000 and 2003 when the number of localities increased to 49 and local populations expanded vigorously (Markowski et al. 2004). In the Gdańsk region S. natans occupies 
Fig. 1 a Location of Gdańsk; b Distribution of the Salvinia palaeobotanical sites (map of the early medieval settlement acc. to Zbierski 1978, simplified): 1- Łagiewniki St., 2Grząska St., 3-Żytnia St., 4-Jaglana St.; c Mean monthly air temperatures in Gdańsk in 1950-1997 (acc. to Miętus 1998) compared with the data from 1998-2008 (acc. to ARMAAG)
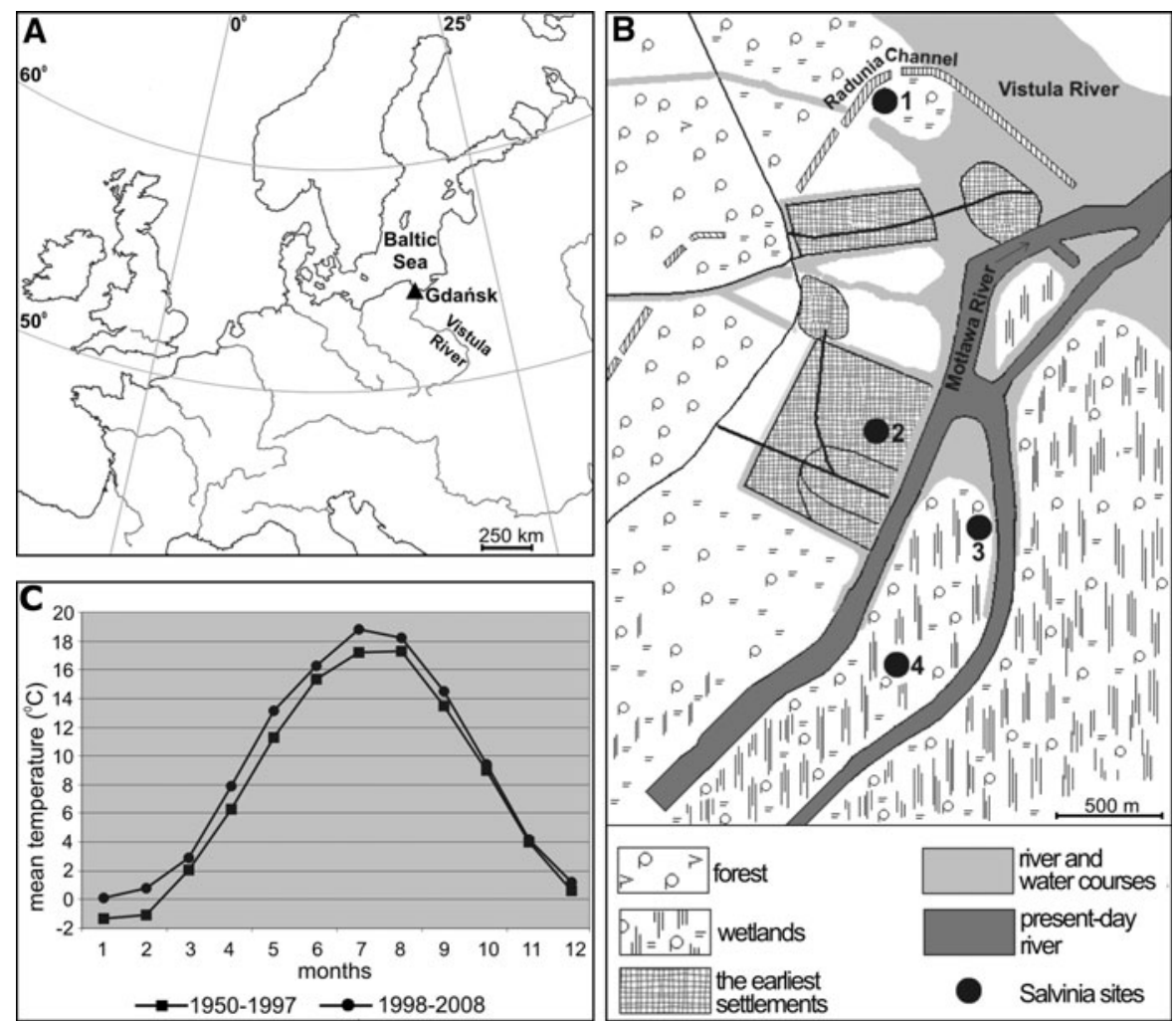

oxbows, ditches and drains supplied with nitrogen and phosphorous compounds, especially in places protected from wind, sun-heated in summers and usually not frozen to the bottom during winter (Gałka 2011). Recently, in many places it has been playing the role of a biological invader, covering water surfaces with a thick floating mat and choking large hydro-regulation systems and waterways. We do not know of any historical sources that tell of a similar proliferation of $S$. natans in this area. The recent expansion in the Gdańsk region has been attributed to the climate warming observed during the last decade (Markowski et al. 2004).

\section{Study site}

Gdańsk lies in the eastern part of the southern Baltic coastal zone, in the vicinity of the Gulf of Gdańsk (Fig. 1a). The climate is typical for the southern Baltic coastal region being under the influence of Atlantic air masses. The long-term mean annual temperature is about $7.5-8^{\circ} \mathrm{C}$, with the maximum average of $17.5^{\circ} \mathrm{C}$ in July and the minimum average of about $-1-0^{\circ} \mathrm{C}$ in January. Mean annual rainfall is below $570 \mathrm{~mm}$ and the relative humidity is about $79 \%$ on an annual scale. Relatively frequent and strong winds, mostly westerly, are typical for this area (Trapp et al. 1987). In the last decade (1998-2008) a clear shift towards warmer conditions has been observed (Fig. 1c). Primarily this concerns the mean temperatures of the coldest period (January-February) which are above $0^{\circ} \mathrm{C}$, a distinct increase in the mean temperatures of April and May and also of July, and late summer and early autumn are also warmer than in the preceding period. Altogether, these factors extend the growing season in the region by about 2 weeks in comparison to the earlier period (217 days in the last decade; calculation based on the data provided by the Agency of Regional Air Quality Monitoring in the Gdańsk metropolitan area-ARMAAG).

In the 10th century an early medieval settlement developed in the forks of the Vistula and Motława Rivers on four areas of slightly higher ground surrounded by wetlands (Fig. 1b). In the following centuries this location, in the proximity of amber resources and at the crossing point of important trading routes, resulted in the rapid development of the town, which gradually also spread onto the wet grounds 
(Paner 2006). Local conditions required protection against floods as well as the acquisition of new dry land. Land reclamation and regulation of the hydrological net accelerated in the 14th century resulting in the transformation of the natural hydrological system. From the mid-15th to the 17th century, Gdańsk was the largest and richest city in the region and one of the largest in Europe (Samsonowicz 1982).

The palaeoecological material discussed in this paper has been collected from four archaeological sites distributed within the historical area of the city of Gdańsk (Fig. 1b).

Site 1- Lagiewniki St., up until the end of the 14th century lay in an area of riverine meadows, which, according to historical sources, were used for hay making and pastures throughout most of the medieval period. The site was immediately settled at the beginning of the 15 th century.

Site 2 at Grzaska St. lies in a former wetland close to the Motława River bank. The oldest cultural layer goes back to the 12th century, but the main occupation phase started here in the 14th century. A distinct isolation layer built of tree branches separates the medieval culture layers and structures from the natural sediments.

Sites 3 and 4 (Żytnia St. and Jaglana St., respectively) are situated on Granary Island, which is separated from the mainland by the arms of the Motława River. Wetlands were extensive in this area up until the 13th century when the first granaries were constructed but some places, for example the area around the site of Jaglana St., were settled as late as the 15 th century. In this area too, it can be seen from the archaeological trenches that thick layers level the surface and separate the natural sediments from the cultural layers and medieval structures (Paner 1993).

\section{Materials and methods}

The paper is based on a selection of pollen and macrofossil data from the sites of Łagiewniki and Jaglana and supplementary macrofossil data from Grząska and Żytnia St., related to the occurrence of aquatic taxa.

Samples for pollen and macrofossil analyses were taken as a vertical series, directly from the trench walls exposed during the archaeological excavations, and then by means of an Instorf corer from the sediments lying beneath the trenches. Technical gaps, each of approximately $10 \mathrm{~cm}$ were established between both sequence types to avoid the risk of contamination. The position (depth) of particular samples is not related to the ground level, but to the depth of sediment that was exposed in the trench wall.

For pollen sampling from the trench walls, syringes were inserted into every $2 \mathrm{~cm}$ of sediment down through the profiles. Each profile section was carefully cleaned immediately before sampling. In the laboratory, $1 \mathrm{~cm}^{3}$ of sediment was collected from the inner part of the syringes and then treated chemically. The profiles obtained by means of the Instorf corer were sampled for pollen analysis in the laboratory. Pollen samples were first processed with $\mathrm{HF}$ to remove silica, and then boiled in $10 \% \mathrm{KOH}$ and acetolysed (Faegri and Iversen 1989). Two Lycopodium tablets (University of Lund, batch 124961) were added to each sample to calculate pollen/spore concentrations (Stockmarr 1971). Non-pollen microfossils (NPPs), i.e. the remains of some algae and other organisms preserved in the pollen samples, were counted along with the pollen (van Geel 2001). For the purposes of this paper, pollen/spore proportions were calculated from a sum including exclusively sporomorphs of the taxa representing aquatic and wetland plants.

For macrofossil analysis, 4-5-cm-thick samples were cut horizontally from the trench walls and put into plastic bags, and $300 \mathrm{~cm}^{3}$ sub-samples were used for this study. Sediments taken with the Instorf corer were cut into $4-5-\mathrm{cm}$-thick slices taking into account the lithological limits. Originally these samples were $40-150 \mathrm{~cm}^{3}$ in volume. The material was immersed in water with a small admixture of $\mathrm{KOH}$ for 24-28 h and then wet-sieved using a column of sieves of 0.2-, 0.5- and 2.8-mm meshes. The whole sample content was segregated using a stereoscopic microscope under $16 \times$ magnification and then determined under 20-120× magnifications. Determinations have been systematically checked against the reference collection in the Laboratory of Palaeoecology and Archaeobotany of the University of Gdańsk. The results of the macrofossil analyses are expressed as the number of specimens per sediment volume unit. Both plant and animal remains are considered.

Principal Component Analysis (PCA) (CANOCO for Windows version 4.5) was performed separately for micro- and macrofossil data to illustrate the interspecies relationships. 
The chronology of the palaeoecological events is based on both archaeological (cultural layers) and radiometric dating. Thirteen samples were radiocarbon dated by the Accelerator Mass Spectrometry
(AMS) method at Poznań Radiocarbon Laboratory, Poland (Table 1). All the dates were obtained from selected fruits and seeds of terrestrial plants isolated from specific layers. To obtain calendar years, the

Table 1 Sediments and radiocarbon dating

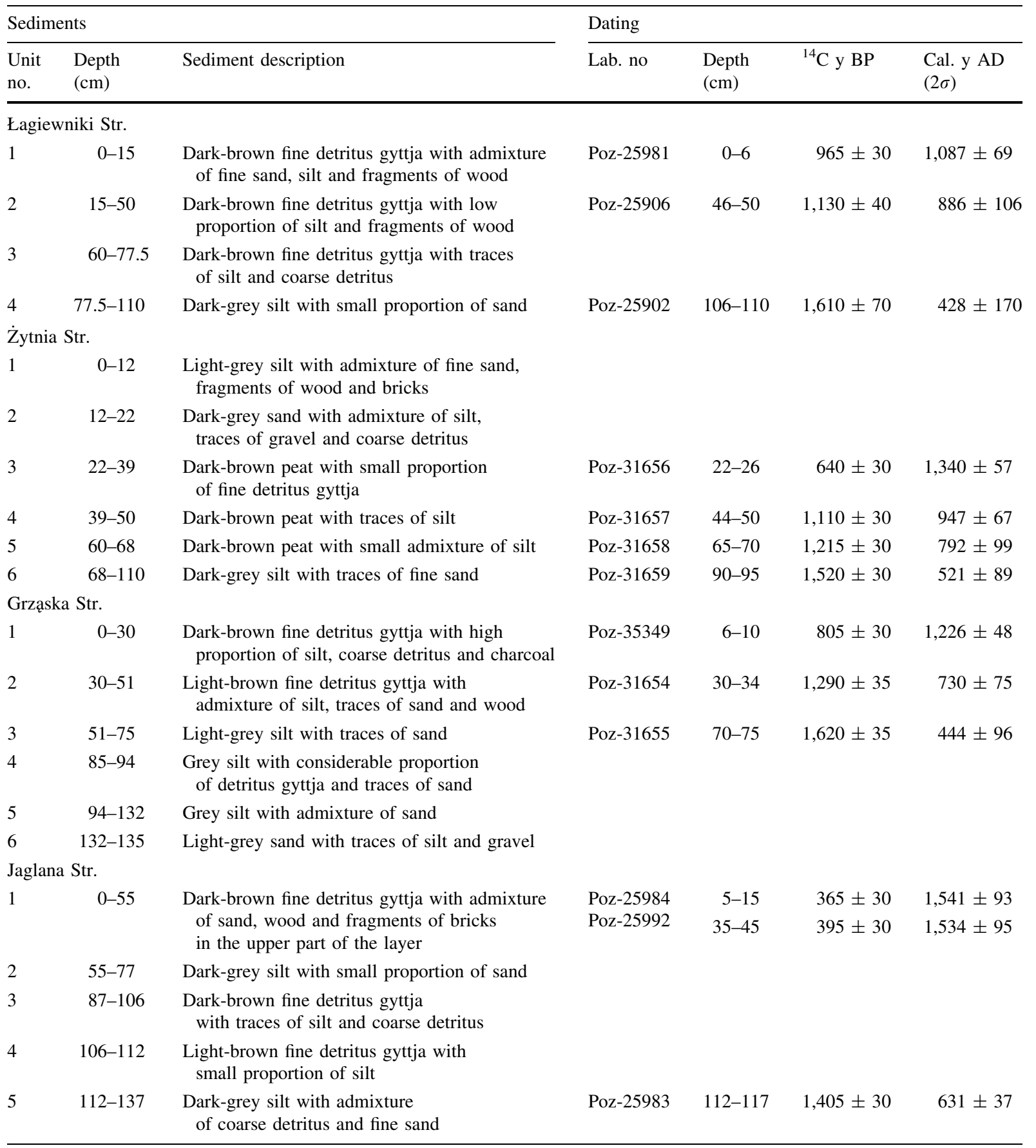


conventional radiocarbon dates were calibrated using OxCal, ver. 4.1, based on the calibration curves IntCal 09 and Marine 09 (Reimer et al. 2009).

\section{Results}

Sediments and their age

At all the sites, the sediments are typically limnogenic, consisting of different proportions of organic and mineral matter, except for Żytnia St. where peat intercalations occur in the bottom part of the profile. Silty sediments with sand and various admixture of detritus gyttja prevail in the lower part of the profiles, while the proportion of organic matter is distinctly higher in their upper parts, showing increasing productivity and shallowing of the water bodies (Table 1).

The radiocarbon (AMS) dating indicates that the age of the sediments ranges from the 5th to the beginning of the 16th century AD (Table 1). In all the profiles, the topmost samples have been taken directly below the archaeological features connected with the first occupation phase of that particular site. The youngest sediments (14th-beginning of the 16th century) occur in the profiles from Granary Island, which is in agreement with the history of this area (Paner 1993).

\section{Palaeoecosystems with Salvinia natans}

The palaeoecological data from all four sites are very similar in the character of the subfossil assemblages, reflecting the composition of the past aquatic ecosystems with $S$. natans (Figs. 2, 3 and 4). However, when interpreting these data we must remember that: (1) due to complex processes shaping the relationship between the composition of a living ecosystem and its fossil remains (Zhao et al. 2006), the quantitative representation of particular taxa in our samples does not reflect the exact proportions of organisms living together in the past, (2) some taxa are represented exclusively by macrofossils and others by microfossils (pollen, spores and others), (3) a single sample contains fossil material from several seasons which may be contrasting with respect to the quantitative representation of particular taxa.

Among the macrophytes, Nymphaceae appear as one of the important constituents of the local vegetation, which is shown by the high proportion of their trichosclereids in the pollen slides (Figs. 2, 3); presence of Nuphar lutea, N. pumila (Timm) DC and Nymphaea alba L. is confirmed by determination their macrofossils. It appears that the frequency of the remains of this group decreases distinctly in those samples with extreme values of $S$. natans; which is shown on the PCA graph (Fig. 5a). Pollen of Sparganium erectum-t. and $S$. emersum-t. are of importance in the palynological material from all the sites although macrofossils of both taxa (fruits) are rather scarce. The presence of Alisma plantagoaquatica $\mathrm{L}$. is confirmed in all the profiles, and this species appears irrespective of the Salvinia occurrences. Stratiotes aloides L. (fruits, leaf spines) has been found in two sites (Fig. 4) together with Salvinia. Seeds of Lemna trisulca and L. gibba L., as well as the remains of other macrophytes, among them Batrachium sp., Najas marina L., Potamogeton lucens L., P. natans L., P. obtusifolius Mert. \& Koch and $P$. perfoliatus L., appear less regularly and in small numbers.

Except for the stoneworts (Chara sp. and Nitella sp.) which occur in our macrofossil material as oospores, other algae and Cyanobacteria were determined from the pollen slides (NPPs). Among them, coccal Chlorophyceae from the genus Pediastrum are especially interesting in the context of the material reported in this paper. Both the visual evaluation of the pollen diagrams (Figs. 2,3) and the results of the PCA (Fig. 5a) show that some of these taxa correlate well with Salvinia. This concerns, primarily, $P$. kawraiskyi and then P. boryanum var. pseudoglabrum, $P$. boryanum var. boryanum and $P$. boryanum var. longicorne.

In our material, especially in the macrofossil samples, some faunal remains are abundant. Statoblasts of Lophopus crystallinus Pallas, 1768 and Cristatella mucedo Cuvier, 1798 (Bryozoa) appear together with Salvinia, it seems, however, that they are negatively correlated each other (Fig. 5b). In all the sites gemmules of freshwater sponges (Porifera, Demospongiae) occur abundantly, also in the layers with large numbers of $S$. natans spores. The remains of others, especially of Daphnia sp. (ephippia), Ostracoda and Turbellaria (cocoons), but also of Acarina (mites) and Oligochaeta (cocoons) disappear or are distinctly less frequent in the samples with high proportions of $S$. natans. 

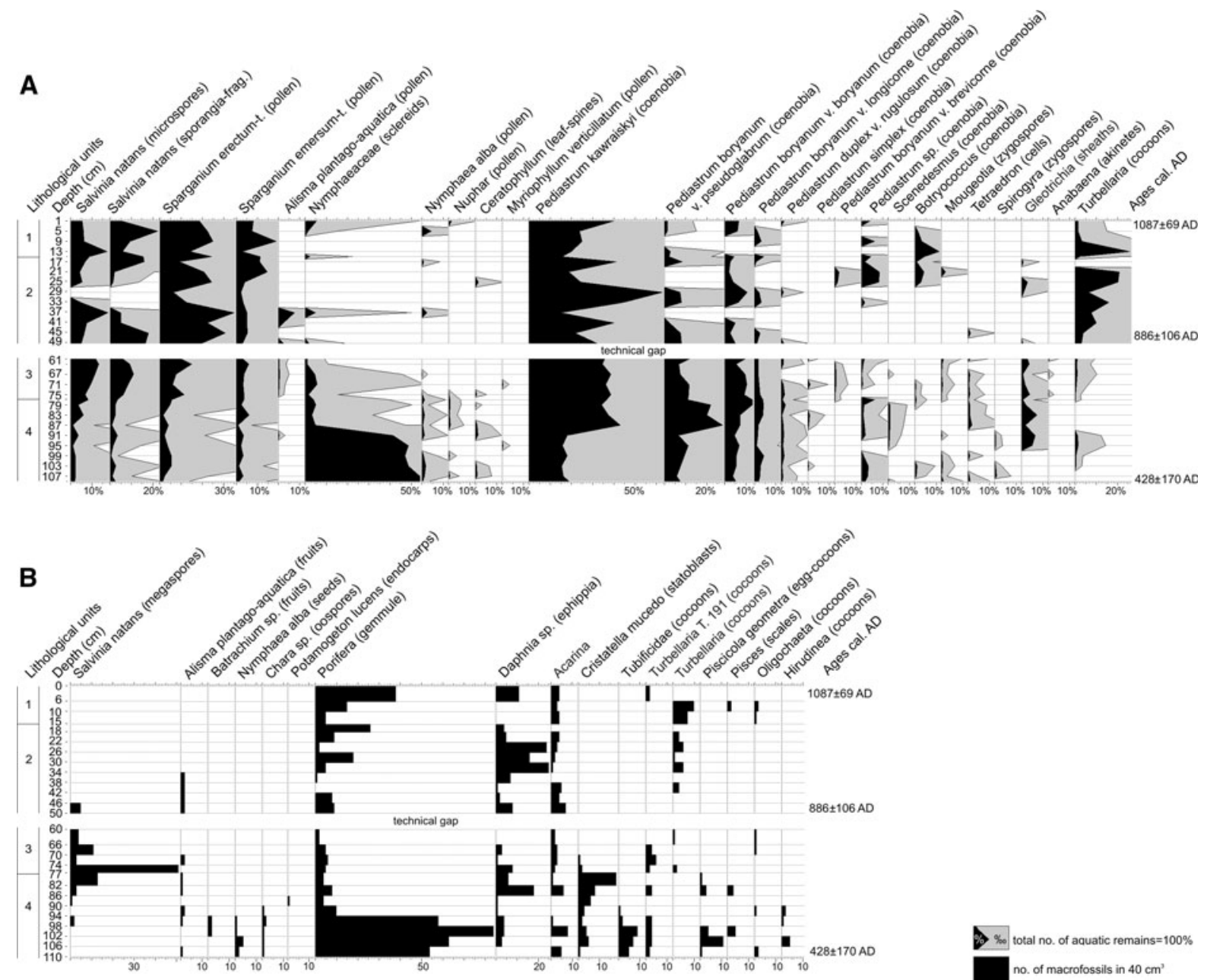

Fig. 2 Selected pollen and NPPs (a) and macrofossil (b) data on the occurrence of aquatic taxa in the Łagiewniki St. profile; for the lithological units see Table 1

Salvinia natans population dynamics

Our data illustrate substantial changes in the S. natans mega- and microspore concentrations in the sediments throughout the medieval period (Fig. 6). The concentration of microspores is always much higher than that of megaspores due to the different productivity of the two sporangia types. Therefore, the microspores are statistically better at illustrating quantitative changes. The maximum concentration of mega- and microspores is approximately 130 per $100 \mathrm{~cm}^{3}$ and about 5,100 per $1 \mathrm{~cm}^{3}$ of sediment, respectively (Łagiewniki and Jaglana St.).

According to these data, $S$. natans already occurred in the water habitats in the mouth of the
Vistula river in the 5th and 6th centuries A.D., but its maximum expansion took place in the 7 th-8th century. Then, it started to decline in the 9th century, but irregular, probably lower occurrences continued up until at least the 16th century (Jaglana St.). The reduction and then disappearance of $S$. natans remains is also evident in the upper sediments which are still rich in macro- and microfossils of other aquatic taxa, illustrating the persistence of potential habitats for Salvinia. Until now, although a large number of other archaeological sites have been investigated in Gdańsk, including those of moats, we have no fossil evidence of $S$. natans in modern times, i.e. from the late 16th century onwards. 


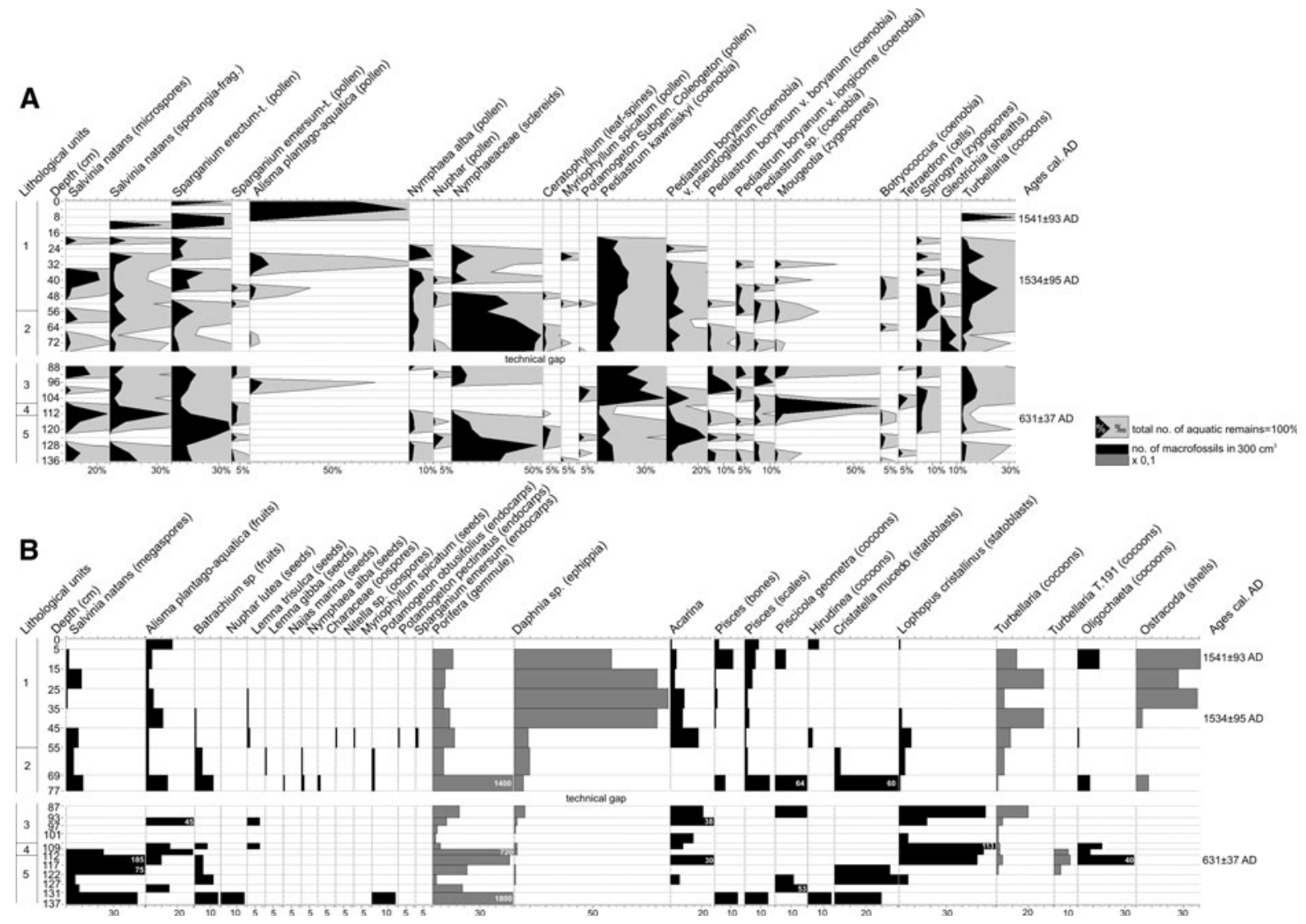

Fig. 3 Selected pollen and NPPs (a) and macrofossil (b) data on the occurrence of aquatic taxa in the Jaglana St. profile; for the lithological units see Table 1

\section{Discussion}

The palaeoecological information on the massive occurrence of $S$. natans in early medieval times in the area of the present-day Gdańsk, combined with knowledge of the factors driving the recent population expansion of this species in the region, allow us to suggest climate warming in the Early Middle Ages, the 7 th-8th century A.D. in particular, and to characterise some thermal parameters of this period.

Our hypothesis that climate warming is the main causal factor that forced past $S$. natans populations to proliferate is based on the fact that in early medieval times, human influence was not present in the region, and during the recent Salvinia expansion, human influence remained unchanged. The most prominent $S$. natans expansion took place in the period preceding human settlement in this area (7th-8th century A.D.). Salvinia started to decline when settlements first began to develop (9-10th century), and Salvinia populations continued at low frequencies throughout the medieval period (up to the 16th century). It disappeared from fossil assemblages until modern times. This decline might partly be a result of local hydrological changes following the development of the town, land reclamation and protection against floods, but our data indicate persistence of potential $S$. natans habitats after the medieval period. Also in the case of the recent proliferation, we observe no anthropogenic factors that might be responsible for this occurrence, such as changes in the hydrology control system, or increased boat traffic (Vistula River is practically unused for river transport). Neither is there evidence for increased eutrophication, nor agricultural runoff. Instead, mild winters, and especially warmer springs with a distinctly longer growing season (Fig. 1c), seem to be decisive factors for the Salvinia population expansion (Gałka 2011). 

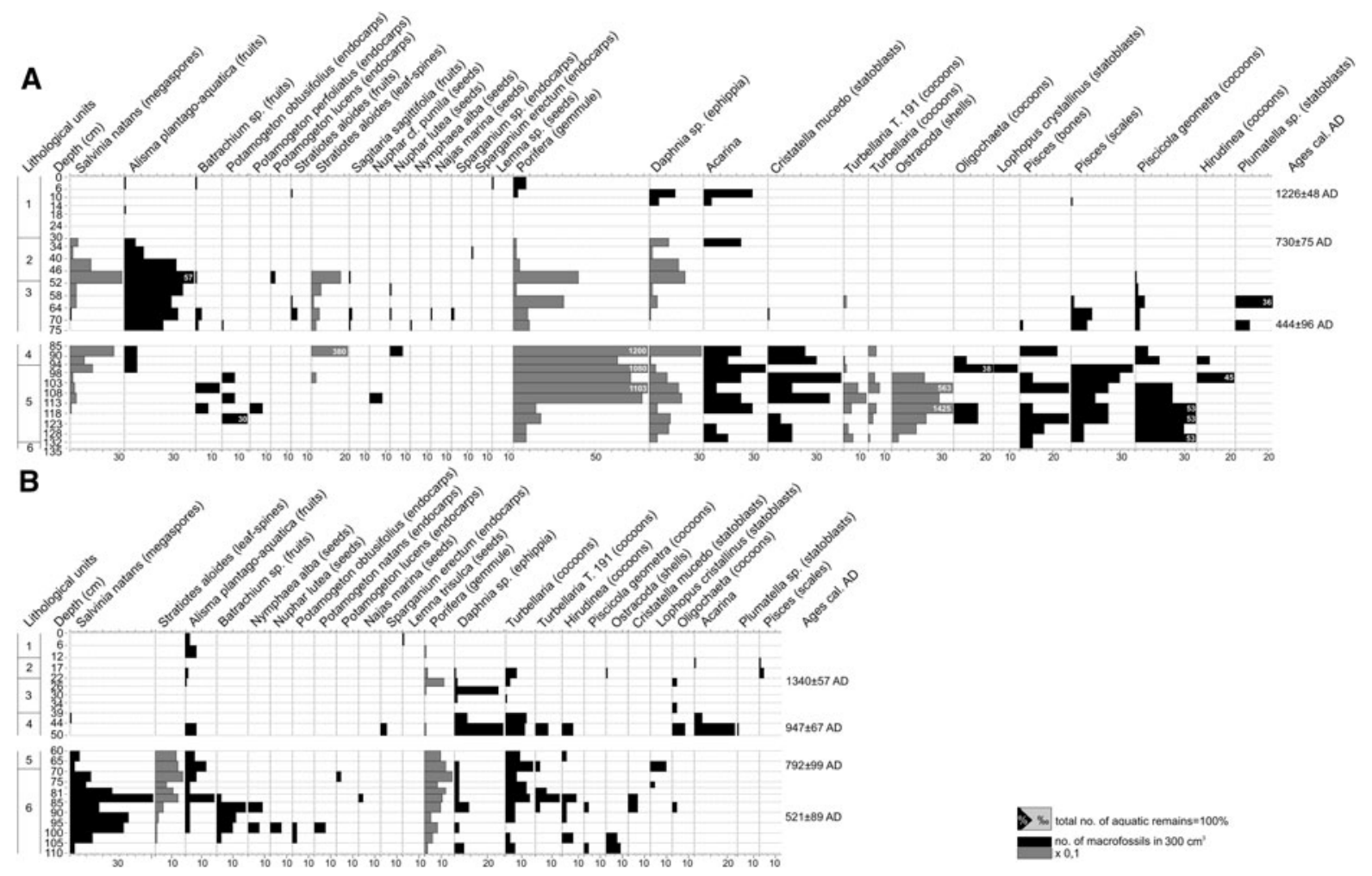

*ot total no. of aquatic remains=100\%

Fig. 4 Selected macrofossil data on the occurrence of aquatic taxa in the Grzaska (a) and Żytnia (b) profiles; for the lithological units see Table 1

Fig. 5 PCA plots

illustrating the inter-species relationships in the pollen spectra from Jaglana and Łagiewniki sites (a) and in the macrofossil samples in all sites (b); the downweighted species were excluded from the analysis

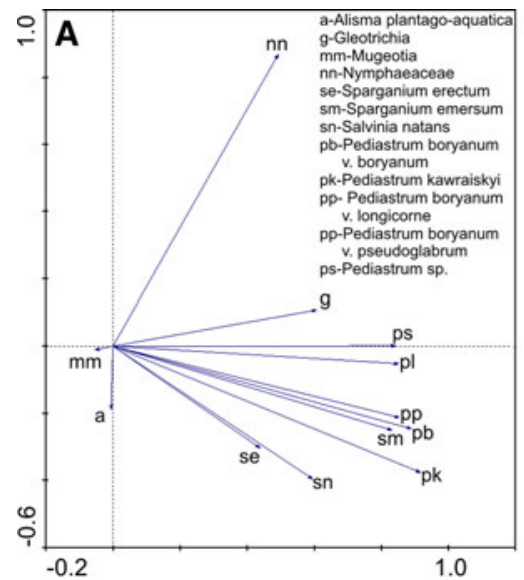

Based on recent observations, we can infer some climatic conditions that might have prevailed in the Vistula deltaic area in the early medieval period. Rather mild winters with mean temperatures around or above $0^{\circ} \mathrm{C}$ are suggested because frost, if it occurred, would not have resulted in freezing of the bottom sediments in shallow water bodies, what is a decisive factor for the survival of the S. natans megaspores (Zutschi and Vass 1971; Gałka 2011). Relatively high spring temperatures and long growing season were necessary for the high reproduction rate of Salvinia, and such seasonality is a primary condition for population expansion. According to field observations in the Gdańsk region and laboratory experiments 


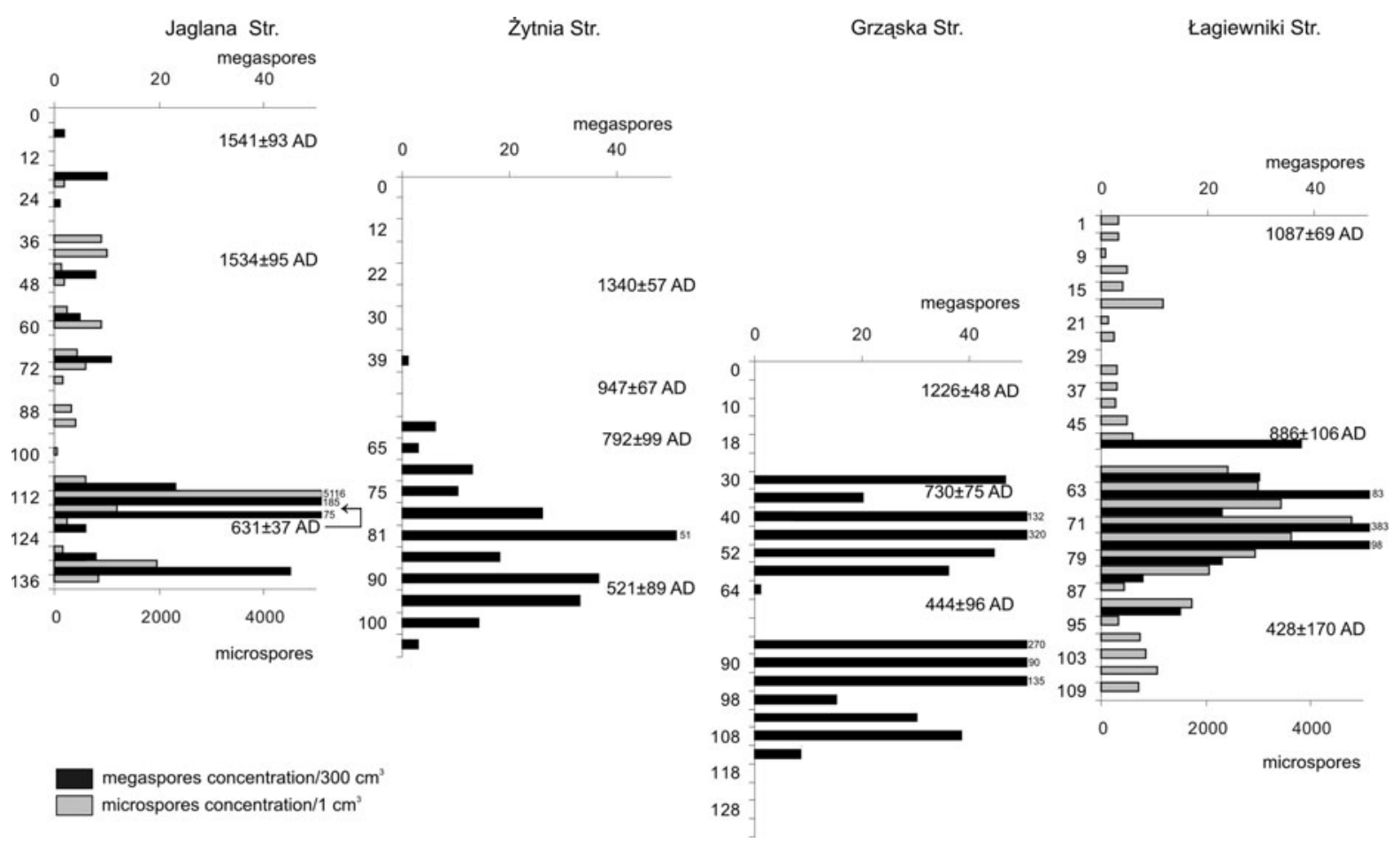

Fig. 6 Salvinia natans micro- and megaspore concentrations in the sediments at all sites

(Gałka 2011), Salvinia needs spring water temperatures around $12.4^{\circ} \mathrm{C}$ for vigorous megaspore germination, and temperatures cannot drop below zero when the gametophyte and the young sporophyte are developing. In the recent decade of vigorous S. natans proliferation, such a thermal condition usually was reached in April, about 1 month earlier than indicated by long-term data for the Gdańsk region (Gałka 2011). It should be emphasized that relatively high water temperatures in April are achieved because of a lack of ice and warmer air temperatures in March. Recent average air temperatures in March $\left(+3^{\circ} \mathrm{C}\right)$ and April $\left(+8^{\circ} \mathrm{C}\right.$; ARMAAG) are respectively about 1 and $2^{\circ} \mathrm{C}$ above the long-term climate normals calculated for the region (Miętus et al. 2002). The longer growing season facilitates vegetative reproduction in particular populations and ensures the time necessary for formation and then maturation of sporocarps in August and September (Zutschi and Vass 1971; Gałka 2011). We may assume that the same factors played a role in the early medieval period. In contrast, during the Little Ice Age and the period that followed in the Gdańsk region, winter and spring frosts probably would have been an important factor limiting $S$. natans until recent times.
According to documentary data from N. Poland, all winter 10-year-mean air temperatures in the period 1501-1840 were distinctly colder than in the 20th century (Przybylak et al. 2005), and mean temperatures in the 20th century were colder than in the decade 1998-2008.

We believe that floods are a secondary factor that probably plays a role in the recent $S$. natans expansion in N. Poland, and could have been important in the past. Floods associated with extreme climate-driven events generally result in escapes of previously confined aquatic species (Walther et al. 2009). With respect to $S$. natans, we can expect some enrichment of the local populations in the Gdańsk region through transportation of sporocarps or spores from the numerous populations in the Upper Vistula valley and its tributaries to the Lower Vistula valley. A more important role probably is played, however, by local hydrologic events that support the dispersal of Salvinia propagules over flooded oxbows, ditches and drains. Floods also can increase eutrophication of surface waters, which is another important factor that can influence the growth of S. natans (Zutschi and Vass 1971). 
Our conclusion linking the Salvinia record with the early medieval climate warming is similar to that of Brinkkemper et al. (2008), who suggested that the sub-fossil Elatine hydropiper and E. hexandra appearances in the Netherlands coincide with warmer climate periods, including the Early Middle Ages. The maximum occurrence of $S$. natans in Gdańsk (7th-8th century A.D.) falls into a period (c. 1350$1200 \mathrm{cal}$. BP) of significant warming (temperatures above the present average) reconstructed for Estonia, a country also lying in the southern Baltic Sea region (Seppä and Poska 2004).

The role of fossil remains of aquatic plants as climate indicators in palaeoecology was demonstrated by Iversen in 1954. The uniformity of the aquatic environment as well as long-distance dispersal, cloning capability, and high phenotypic plasticity are among the most important factors that enable the wide geographic distribution of aquatic plants (Santamaría 2002; Szmeja et al. 2008), and these factors also are responsible for their rapid expansion in response to climate warming. Macrophyte communities in shallow waters are especially exposed to climate change (Mulholland et al. 1997; Mckee et al. 2002). Temperature is mentioned as the most important abiotic factor influencing their growth and reproduction (Carr et al. 1997; van der Heide et al. 2006). Recent studies have also shown that the minimum growth temperature of pleustophytes (free-floating plants) is decisive in their ability to colonize new areas (Stachowicz et al. 2002; van der Heide et al. 2006). It has been observed that rising temperatures are changing both the population dynamics of native species and the ability of alien species to expand into new areas, and warm-weather species are pushing towards higher latitudes. This is causing changes in the structure, composition and functioning of ecosystems (Rooney and Kalff 2000; Walther et al. 2002, 2009).

Our records suggest that in the early medieval period, the population density of $S$. natans was similar to or higher than that observed today in shallow waters invaded by this species in the Gdańsk region. According to Włodarczyk (2008), today in the water bodies densely covered by Salvinia, the average concentration of microspores is about 200 per $5 \mathrm{ml}$ of sediment and the concentration of megaspores does not exceed 3 per $5 \mathrm{ml}$ of sediment. The above values are much lower than these obtained for the sub-fossil material in the present study. Even keeping in mind that the spore concentration values for the recent and fossil sediments (unknown number of years) are not directly comparable, these data enable us to conclude that in the early medieval period, in the Vistula deltaic area, S. natans appeared abundantly and probably played the role of an invasive plant.

As shown by many studies, the expansion of any invasive species usually causes a dramatic shift in the whole ecosystem (Zedler and Rea 1998; Walther et al. 2009). There is ample literature on the invasive abilities of the Salvinia species, especially of S. molesta which invades shallow waters in large areas of the tropics and sub-tropics around the World (Oliver 1993). However, S. natans is also known as an invasive species (Zutschi and Vass 1971; Markowski et al. 2004). The expansion of $S$. natans in aquatic environments causes important changes in local conditions, including overshadowing, that restricts primary production by phytoplankton and all submerged and benthic organisms, oxygen depletion and a high production of biomass, which, in the subsequent process of decomposition at the end of the growing season, becomes an important factor increasing the trophy of the habitat (Zutschi and Vass 1971). It is a question if our palaeoecological data may reflect such processes in past ecosystems.

The ecological mechanisms of macrophyte community response to increased temperatures are well documented in recent studies. In middle latitudes, where climate warming prevents ice formation during the winter, both temperature and light intensity promote early, rapid phytoplankton blooms and macrophyte proliferation. Phytoplankton blooms are followed by depletion of limnetic nutrient concentrations, which leads to phytoplankton decline, and plankton biomass decomposition promotes subsequent growth of macrophytes (Aseda et al. 2001; Mckee et al. 2002). Our study suggests that similar processes occurred in the aquatic ecosystems in medieval Gdańsk. High abundances of light-demanding planktonic green algae in samples with high numbers of $S$. natans remains probably indicate early phytoplankton blooms in late spring or early summer, followed by development of $S$. natans sporophytes.

One of the most important reactions of an ecosystem subjected to biological invasion is decreased biodiversity (Pieterse and Murphy 1990). Our data point to a temporal decline in the abundance of some aquatic taxa in the phases related to the early 
medieval $S$. natans population expansion. This concerns Nuphar lutea, N. pumila and Nymphaea alba as well as some representatives of the aquatic fauna, with Daphnia sp., Ostracoda, Turbellaria, mites and Oligochaeta among them. We can suggest oxygen depletion, due to overgrowth of the water surface by a carpet of Salvinia, as the most likely factor limiting development of these organisms. On the other hand, during its development $S$. natans tends to limit nitrogen and phosphorous concentrations in the water column (Staniszewski et al. 2004; Xi et al. 2006). Our fossil material suggests that this occurred during the past as well. In all our sites, gemmules of freshwater sponges (Porifera, Demospongiae) occur abundantly, as well as in layers with large numbers of $S$. natans spores. Also, statoblasts of Lophopus crystallinus and Cristatella mucedo (Bryozoa), appear together with Salvinia. Both groups-Bryozoa and Porifera are sessile, colonial, filter-feeding animals. The close co-occurrence of these taxa with Salvinia (Fig. 5b) suggests that Salvinia was probably colonized by these organisms, and that it played a role in providing them with oxygen.

S. natans is infrequently recorded in Holocene deposits in Europe. Among these few records, large numbers of microspores and fragments of sporangia of this fern in the mid-Holocene sediments in the Szczecin Lagoon, S. Baltic Sea (Latałowa and Święta 2003) are worthy of notice. In our opinion, this abundance might have been caused by transportation due to floods along the lagoon's shores and in oxbows in the lower Odra River valley. Similar records, dating to the Atlantic period, have been obtained from the Rhine River valley in the Netherlands (Zandstra 1966; Out 2008). The Holocene history of $S$. natans populations in the Gdańsk region is unknown, but on the basis of data from the lower Rhine and Odra River valleys, it might be suggested that this species has appeared in the Vistula deltaic area at least since the Atlantic period.

Generally, in Central Europe micro- and megaspores of $S$. natans are much more frequent in the deposits from the earlier interglacials than in Holocene deposits. They are recorded especially in the optimum phase of the Eemian and Masovian (Holsteinian) interglacials, as has been shown in several Polish studies of those periods (Mamakowa 1989; Bińka et al. 1997). Therefore, in Central Europe, Quaternary finds of $S$. natans correspond to the warmer periods.
According to Mamakowa (1989), very high concentrations of $S$. natans micro- and macroremains in the Eemian site of Imbramowice suggest the formation of phytocoenoses similar to the present-day Lemno minoris-Salvinietum natantis in Poland (MichalskaHejduk and Kopeć 2002), while concurrent decrease in the remains of other macrophytes seems to illustrate impoverishment of the palaeoecosystem due to Salvinia expansion. Those results are similar to the data described from early medieval Gdańsk.

\section{Conclusions}

Climate parameters have been a major factor for population expansion of Salvinia natans in the Gdańsk region during the last decade, and mild winters with mean temperatures around or above $0^{\circ} \mathrm{C}$ have increased the survival of spores. Relatively high spring temperatures without frosts induced early vigorous germination and high survival rate of the gametophytes and young sporophytes. During the early medieval period (especially in the 7th-8th century), oxbows and slowly moving waters in the mouth of the Vistula River were subjected to a $S$. natans population expansion, which probably resulted from climate warming similar to the present time. The longer growing season insured effective multiplication of the vegetative generations and maturation of the sporocarps. The appropriate thermal conditions were, most likely, decisive for the S. natans blooms, while floods played a secondary role that enabled effective transportation of sporocarps through waterways, and increased limnetic nutrient concentrations that promoted the development of this species. Our data suggest that high $S$. natans population density might have been a limiting factor for the development of some macrophytes and other aquatic organisms due to shading of the habitat and oxygen depletion in the ecosystem. Nevertheless, massive development of this fern apparently created new habitats for some colonial sessile organisms, including bryozoa and sponges. It seems that the $S$. natans "bloom" in the Early Middle Ages may be regarded as an extraordinary occurrence that has an analogue in the climate-driven population expansion of this species during the last decade.

A subsequent $S$. natans population decline started gradually around the 9th century, but $S$. natans 
persisted in the area up to at least the 16th century. It probably disappeared from the Gdańsk region in the Little Ice Age due to climate cooling, but temporal reappearances of small populations might have occurred, as confirmed by historical written sources from the late 19th century (Abromeit et al. 1940).

Acknowledgments The authors would like to thank Grażyna Żelazna for her technical help in the preparation of the macrofossil samples and Ewelina Buba and Justyna Kotasour former undergraduate students - for their work on the MSc theses that substantially helped to supplement the data on the occurrence of S. natans in archaeological sites in Gdańsk. We also thank Sheila Hicks for revising the English and commenting on the manuscript and Thomas J. Whitmore and two anonymous reviewers for constructive remarks. Meteorological data were shared by ARMAAG Foundation in Gdańsk. The paper is based on the results obtained in the project N305081 31/3181 funded by the Ministry of Sciences and Higher Education in Poland.

Open Access This article is distributed under the terms of the Creative Commons Attribution Noncommercial License which permits any noncommercial use, distribution, and reproduction in any medium, provided the original author(s) and source are credited.

\section{References}

Abromeit J, Neuhoff W, Steffen H (1940) Flora von Ost- und Westpreussen, 6. Kommissionsverlag Gräfe und Unzer, Berlin-Königsberg

Aseda T, Trung VK, Manatunge J, Bon TV (2001) Modelling macrophyte-nutrient-phytoplankton interactions in shallow eutrophic lakes and evaluation of environmental impacts. Ecol Eng 16(3):341-357

Behre K-E, Jacomet S (1991) The ecological interpretation of archaeobotanical data. In: van Zeist W, Wasylikowa K, Behre KE (eds) Progress in old world palaeoethnobotany. A.A. Balkema, Rotterdam-Brookkfield, pp 81-108

Bińka K, Lindner L, Nitychoruk J (1997) Geologic-floristic setting of the Mazovian Interglacial sites in Wilczyn and Lipnica in southern Podlasie (Eastern Poland) and their palaeogeographic connections. Geol Qt 41(3):381-394

Brinkkemper O, Weeda EJ, Bohncke SJP, Kuijper WJ (2008) The past and present occurrence of Elatine and implications for palaeoenvironmental reconstructions. Veg Hist Archaeobot 17:15-24

Carr GM, Duthie HC, Taylor WD (1997) Models of aquatic plant productivity: a review of the factors that influence growth. Aquat Bot 59:195-215

Casper SJ, Krausch HD (1980) Pteridophyta und Anthophyta. 1. Lycopodiaceae bis Orchidaceae. In: Ettl H, Gerlof J, Heyning H (eds) Suswasserflora von Mitteleuropa Bd. 23. G. Fischer Verl, Jena
Dukes JS, Mooney HA (1999) Does global change increase the success of biological invaders? Trends Ecol Evol 14(4): 135-139

Faegri K, Iversen J (1989) Textbook of Pollen Analysis. Wiley, Chichester

Gałka A (2011) Biologia i ekologia ekspansywnych populacji Salvinia natans (L.) All. w delcie Wisły. PhD thesis in the Faculty of Biology, University of Gdańsk. Gdańsk [Biology and ecology of the expansive populations of Salvinia natans (L.) All. in the Vistula deltaic area]

Herzog R (1938) Geographische Verbreitung der gattungen Salvinia und Azolla. Bot Arch 39:219-225

Holm L, Pancho JV, Herberger JP, Plucknett DL (1979) A geographical atlas of world weeds. Wiley, New York

Iversen J (1954) The Late-glacial flora of Denmark and its relation to climate and soil. Danm Geol Unders II 80:87-119

Kozáková R, Pokorný P, Havrda J, Jankovská V (2009) The potential of pollen analyses from urban deposits: multivariate statistical analysis of a data set from the medieval city of Prague, Czech Republic. Veg Hist Archaeobot 18:477-488

Latałowa M, Święta J (2003) Późnoglacjalna i holoceńska sukcesja roślinności lokalnej na obszarze Zalewu Szczecińskiego. In: Borówka RK, Witkowski A (eds) Człowiek i środowisko przyrodnicze Pomorza Zachodniego II. Oficyna IN PLUS, Szczecin, pp 123-129 [The Late-glacial and Holocene succession of local vegetation in the area of Szczecin Lagoon]

Latałowa M, Badura M, Jarosińska J (2003) Archaeobotanical samples from non-specific urban contexts as a tool for reconstructing environmental conditions. Veg Hist Archaeobot 12:93-104

Latałowa M, Święta-Musznicka J, Pędziszewska A (2009) Źródła paleobotaniczne do rekonstrukcji wczesnych etapów rozwoju Gdańska. In: Kittel P, Forysiak J, Domańska L (eds) Środowiskowe uwarunkowania lokalizacji osadnictwa. Środowisko-Człowiek-Cywilizacja 2. Stowarzyszenie Archeologii Środowiskowej, Łódź, pp 175-185 [Palaeobotanical sources for reconstructing early stages of Gdańsk development]

Leroy SAG (1992) Palynological evidence of Azolla nilotica Dec. in recent Holocene of the eastern Nile Delta and palaeoenvironment. Veg Hist Archaeobot 1:43-52

MacDougall AS, Turkington R (2005) Are invasive species the drivers or passangers of change in degraded ecosystems? Ecology 86:42-55

Mamakowa K (1989) Late Middle Polish Glaciation, Eemian and Early Vistulian vegetation at Imbramowice near Wrocław and the pollen stratigraphy of this part of the Pleistocene in Poland. Acta Palaeobot 29(1):11-176

Markowski R, Żółkoś K, Bloch-Orłowska J (2004) Salvinia natans (L.) All. na Pomorzu Gdańskim. Acta Bot Cass 4:187-196 [Salvinia natans (L.) All. in Gdańskie Pomerania]

Mckee D, Hatton K, Eaton JW, Atkinson D, Atherton A, Harvey I, Moss B (2002) Effect of simulated climate warming on macrophytes in freshwater microcosm communities. Aquat Bot 74:71-83

Michalska-Hejduk D, Kopeć D (2002) Lemno minorisSalvinietum natantis i Hydrocharitetum morsus-ranae $\mathrm{z}$ udziałem Salvinia natans w starorzeczach Sanu i propozycje ich ochrony. Fragm Florist Geobot Pol 9:319-328 [Lemno minoris-Salvinietum natantis and Hydrocharitetum 
morsus-ranae with Salvinia natans in old river-beds of the river San (Poland) and proposals of their protection]

Miętus M (1998) O rekonstrukcji i homogenizacji wieloletniej serii średniej miesięcznej temperatury ze stacji w Gdańsku-Wrzeszczu, 1851-1995. Wiad IMGW 21(42), 2: 41-63 [The reconstruction and homogenization of longterm series of monthly mean temperature from GdańskWrzeszcz station, 1851-1995]

Miętus M, Owczarek M, Filipiak J (2002) Warunki termiczne na obszarze Wybrzeża i Pomorza w świetle wybranych klasyfikacji. Materiały Badawcze. Seria: Meteorologia 36. Instytut Meteorologii i Gospodarki Wodnej, Warszawa [Thermal conditions on the Polish Coast and in the Pomerania Region on the background of some classification]

Mulholland PJ, Best GR, Coutant CC, Hornberger GM, Meyer JL, Robinson PJ, Stenberg JR, Turner RE, Vera-Herrera F, Wetzel RG (1997) Effects of climate change on freshwater ecosystems of the southeastern United States and the gulf coast of Mexico. Hydrol Process 11(8):949-970

Oliver JD (1993) A review of the Biology of Giant Salvinia (Salvinia molesta Mitchell). J Aquat Plant Manag 31: 227-231

Out WA (2008) Neolithisation at the site Brandwijk-Kerkhof, the Netherlands: natural vegetation, human impact and plant food subsistence. Veg Hist Archaeobot 17:25-39

Paner H (1993) Wyspa Spichrzów w Gdańsku. Pomorania Antiqua 15:155-188 [Granary Island, Gdańsk]

Paner H (2006) Archeologia Gdańska w latach 1988-2005. In: Paner H (ed) Archeologia Gdańska T.I. Muzeum Archeologiczne w Gdańsku, Gdańsk, pp 11-88 [Archaeology in Gdańsk 1988-2005]

Pieterse AH, Murphy KJ (1990) Aquatic weeds. The ecology and management of nuisance aquatic vegetation. Oxford University Press, Oxford

Pokorný P, Boenke N, Chytrácek M, Novákov K, Sádlo J, Veselý J, Kuneš P, Jankovská V (2006) Insight into the environment of a pre-Roman Iron Age hillfort at Vladar, Czech Republic, using a multi-proxy approach. Veg Hist Archaeobot 15:419-434

Przybylak R, Majorowicz J, Wójcik G, Zielski A, Chorążyczewski W, Marciniak K, Nowosad W, Oliński P, Syta K (2005) Temperature changes in Poland from the 16th to the 20th centuries. Int J Climatol 25:773-791

Reimer PJ, Baillie MGL, Bard E, Bayliss A, Beck JW, Blackwell PG, Bronk Ramsey C, Buck CE, Burr GS, Edwards RL, Friedrich M, Grootes PM, Guilderson TP, Hajdas I, Heaton TJ, Hogg AG, Hughen KA, Kaiser KF, Kromer B, McCormac FG, Manning SW, Reimer RW, Richards DA, Southon JR, Talamo S, Turney CSM, van der Plicht J, Weyhenmeyer CE (2009) IntCal09 and Marine09 radiocarbon age calibration curves, 0-50,000 years cal BP. Radiocarbon 51(4):1111-1150

Rejmánek M (1995) What makes a species invasive? In: Pyšek P, Prach K, Rejmánek M, Wade PM (eds) Plant Invasions: general aspects and special problems. Academic Publishing, Amsterdam, pp 1-13

Rooney N, Kalff J (2000) Inter-annual variation in submergent macrophyte community biomass and distribution: the influence of temperature and lake morphometry. Aquat Bot 68:321-335
Samsonowicz H (1982) Dynamiczny ośrodek handlowy. In: Cieślak E (ed) Historia Gdańska. Tom II, 1454-1655. Wydawnictwo Morskie, Gdańsk, pp 93-175 [Dynamically expanding trade centre]

Santamaría L (2002) Why are most of aquatic plants widely distributed? Dispersal, clonal growth and small-scale heterogeneity in a stressful environment. Acta Oecol 23:137-154

Seppä H, Poska A (2004) Holocene annual mean temperature changes in Estonia and their relationship to solar insolation and atmospheric circulation patterns. Q Res 61:22-31

Stachowicz JJ, Terwin JR, Whitlatch RB, Osman RW (2002) Linking climate change and biological invasions: ocean warming facilities non-indigenous species invasions. Proc Natl Acad Sci USA 99:15497-15500

Staniszewski R, Szoszkiewicz J, Tomoń M (2004) The Role of Selected Plants in Limitation of Freshwater Trophy with Emphasis on Salvinia natans (L.) All. Pol J Environ Stud 13(Suppl 1):67-69

Stockmarr J (1971) Tablets with spores used in absolute pollen analysis. Pollen Spores 13:615-621

Szmeja J, Clement B, Bociąg K, Gałka A, Skurzyński P (2008) Biomass allocation to anchoring structures in the aquatic macrophytes from the subcontinental and Atlantic climates in Europe. Acta Soc Bot Pol 77(2):117-123

Trapp J, Korzeniewski J, Nurek T, Wyszkowski A (1987) Klimat aglomeracji gdańskiej. Zeszyty Naukowe Wydziału Biologii i Nauk o Ziemi, Uniwersytet Gdański, Geografia 16: 5-33 [The climate of the Gdańsk agglomeration]

van der Heide T, Roijackers RMM, van Nes EH, Peeters ETHM (2006) A simple equation for describing the temperature dependent growth of free-floating macrophytes. Aquat Bot 84:171-175

van Geel B (2001) Non-pollen palynomorphs. In: Smol JP, Birks HJB, Last WM (eds) Tracking environmental change using lake sediments. 3, Terrestrial Algal, and Siliceous Indicators. Kluwer Academic Publishers, Dordrecht-London, pp 99-120

Walther G-L, Post E, Convey P, Menzel A, Paresan C, Beebe TJC, Fromentin JM, Hoegh-Guldberg O, Bairlein F (2002) Ecological responses to recent climate change. Nature 416:389-395

Walther G-L, Roques A, Hulme PE, Sykes MT, Pyšek P, Kühn I, Zobel M (2009) Alien species in a warmer world: risks and opportunities. Trends Ecol Evol 24(12):686-693

Włodarczyk Ł (2008) Dynamika populacji Salvinia natans (L.) All. w Gdańsku Owczarni. MSc Thesis in the Faculty of Biology, Geography and Oceanology, University of Gdańsk. Gdańsk [Population dynamics of Salvinia natans (L.) All. in Gdańsk Owczarnia]

Wolters S, Bittmann F, Kummer V (2005) The first subfossil records of Urtica kioviensis Rogow. and their consequences for palaeoecological interpretations. Veg Hist Archaeobot 14:518-527

Xi Y, Xiang-Jun L, Fu-Chen S (2006) Study on Purifying Effect of Salvinia natans in Eutrophicate Water. J Tianjin Norm Univ 26(3):19-22

Zandstra KJ (1966) The occurrence of Salvinia natans (L.) in Holocene deposits of the Rhine delta. Acta Bot Neerl 15:389-393

Zbierski A (1978) Rozwój przestrzenny Gdańska w 9-13 wieku. In: Cieślak E (ed) Historia Gdańska. Vol. 1 do 
roku 1454. Wydawnictwo Morskie, Gdańsk, pp 71-125 [The spatial development of Gdańsk in 9th-13th c.]

Zedler JB, Rea N (1998) Introduction. Ecology and Management of Wetland Plant Invasions. Wetl Ecol Manag 5:161-163

Zhao Y, Sayer CD, Birks HH, Hughes M, Peglar SM (2006) Spatial representation of aquatic vegetation by macrofossils and pollen in a small and shallow lake. J Paleolimnol 35:335-350

Zutschi DP, Vass KK (1971) Ecology and production of Salvinia natans Hoffim in Kashmir. Hydrobiologia 38: 303-320 